\section{Per Halvor Andreassen}

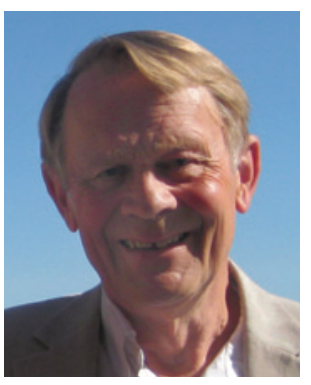

30.7. 2013 døde vår kjære kollega, pensjonert overlege Per Halvor Andreassen, 76 år gammel. Han var født i Kristiansand og studerte medisin i Heidelberg i Tyskland, der han tok eksamen i 1962.

Tjeneste og spesialisering ved sykehusene i Aker, Sarpsborg og Akershus ga ham bred og solid oversikt over det indremedisinske fagfeltet. Han kom til Horten sykehus som assisterende overlege og spesialist i indremedisin i 1974. Her fikk han raskt en sentral posisjon, takket være sine gode evner som kliniker, sine menneskelige egenskaper og sin store arbeidskapasitet. Hans milde, sørlandske vesen, hans hjelpsomhet og hans samarbeidsevner gjorde ham avholdt hos pasienter og ansatte.

I 1984 ble han avdelingsoverlege og viste at han også hadde gode lederegenskaper. Medisinsk avdeling i Horten var veldrevet og effektiv under Pers ledelse. Den var i flere år landets mest kostnadseffektive. Ved avdelingen kunne man også i mange år rose seg av ikke å ha pasientklager i det hele tatt.

Ikke mange norske sykehusavdelinger har kunnet skilte med at alle innlagte pasienter fikk visitt av overlege og spesialist hver dag. Mange er de turnus- og assistentleger som fikk en god start på sykehusutdanning og spesialisering i Pers avdeling.

Med årene ble han alvorlig syk. Trass i dette var han kun borte fra sykehusarbeidet når det var nødvendig av hensyn til behandling og undersøkelser av sin sykdom.

Sentraliseringsprosessen i Vestfold førte til at sykehuset ble avviklet i år 2000 og pasienter og personell overført til Sykehuset i Vestfold, Tønsberg.

Per arbeidet som overlege der ved Seksjon for blodsykdommer frem til pensjonering.

Som pensjonist var han fortsatt aktiv og engasjert. Hans store, nære familie har nå mistet et naturlig midtpunkt.

Med takknemlighet og gode minner

Morten Bækkevar

Arne Hasvoll

Jon Anders Takvam

Karl Erik Viken

\section{Meldte dødsfall}

Dødsfall kan meldes til Legeforeningens medlemsseksjon, tlf.23109185 eller register@legeforeningen.no

Per Halvor Andreassen 22.6. 1937-30.7. 2013

Arne Bøe 24.6. 1958-8.8. 2013

Ivar Paul Enge 12.9. 1922-18.7. 2013

Erik Engebjerg 3.6. 1937-4.8. 2013

Knut Graham 28.12. 1924-1.4. 2013

Margrethe K. H. Hagen 22.4. 1917-24.8. 2013

Per Erik Røste 8.7. 1943-29.6. 2013

Inger Marie Schou-Sjølie 4.10. 1935-5.8. 2013

Torbjørn Sollund 25.2. 1944-15.7. 2013

Rolf Peder Tennebø 2.8. 1973-30.7. 2013

Ben William Walther 25.1. 1921-23.6. 2013

Einar Alsaker Wiig 5.1. 1924-9.8. 2013

Jan Fredrik Ziesler 25.2. 1923-4.8. 2013 